\title{
Indonesian Modified Clay for Dye Waste Treatment
}

\author{
Iwan Sumarlan $^{1^{\star}}$, Is Fatimah ${ }^{2}$, Karna Wijaya ${ }^{3}$ \\ ${ }^{1}$ Chemistry Department, Faculty of Science, Mataram University, Indonesia \\ ${ }^{2}$ Chemistry Department, Faculty of Science, Islamic University of Indonesia,, Indonesia \\ ${ }^{3}$ Chemistry Department, Faculty of Science, Gadjah Mada University, Indonesia \\ *Email: i.sumarlan@unram.ac.id
}

Received March 4, 2019; Accepted February 08, 2020

\begin{abstract}
Synthesis and characterization of $\mathrm{TiO}_{2}$ coated on clay pillared alumina (PILC) for methyl orange photodegradation under uv illumination. The synthesis included both pillarization the clay with alumina and $\mathrm{TiO}_{2}$ coated on PILC using impregnation method. Some characterizations also were employed to this research such as X-Ray Diffraction (XRD), Scanning Electron Microscopy (SEM), $\mathrm{N}_{2}$ Adsorption Isotherm and UV-Visible Diffuse Reflectance (DR UV). The photocatalyst was then used to decompose waste dye, methyl orange (MO). Among three photocatalysts that were successfully synthesized, PILC Ti $1.0 \%$ had the highest activity to decompose the waste dye.
\end{abstract}

Keywords: $\mathrm{TiO}_{2}$, Pillarization, Clay, Methyl Orange

\section{INTRODUCTION}

For many years, dye waste from textile industry has gained attention because of its toxicity and harmful effect for human being. According to the report, there are over $7 \times 10^{5}$ tons of dye waste produced annually in the world and some of these wastes were plunged directly into rivers without any treatments. Dye waste with its existence in the water has characteristic such as stable to the light and heat, difficult to remove, and nonbiodegradable.

Some methods have been employed to get water cleaned from such dye such as photo degradation, ozonation, adsorption, electrochemical and biological treatment and coagulation [1] and Fenton's oxidation as well [2]. Among those methods, photo degradation is the most suitable and proper compared to the rest methods [3]. The main advantage of this method is the ability to mineralize the dye into $\mathrm{CO}_{2}$ and $\mathrm{H}_{2} \mathrm{O}$ in which these two compounds are less toxic and friendlier to environment.

Titania $\left(\mathrm{TiO}_{2}\right)$ has been known long time for photocatalytic reaction agent due to nontoxic, inexpensive and high photocatalytic activities. As semiconductor, $\mathrm{TiO}_{2}$ has band gab energy $(\mathrm{Eg}=3.2 \mathrm{eV})$ that can be activated by illuminating the UV light either from lamp or sun [4]. However, in the bulky form of $\mathrm{TiO}_{2}$, its performance is not as good as in the nano size form and tends to decrease. One technic to make it in nano size in order to overcome the problem is to disperse it into porous materials such as zeolite [5], carbon nano tube (CNT) [6], silica pore [7], etc. In this research, we used clay as host material because it is considered simply to find, low cost, nontoxic, renewably natural and it provides large capacity for dispersion as well. To make clay surface area rise, we also conducted pillarization. Pillarization is to put metal oxide as a pillar in between two layers of clay using impregnation method so that the basal spacing of the layers will increase by its self [8-10]. Alumina (Al2O3) was employed as pillar rather than $\mathrm{TiO} 2$ in order to firm clay structure at low $\mathrm{pHs}$ whereas $\mathrm{TiO} 2$ pillar will collapse in that circumstance [11]. Finally, in this paper Methyl Orange (MO) has been proposed as a sample representative of dye waste (figure 1 ).

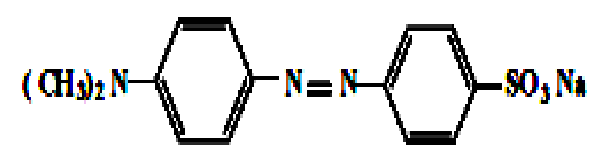

Figure 1: Methyl Orange

\section{MATERIALS AND METHODS}

\section{Materials}

The clay was purchased at PT. Tunas Inti Makmur Semarang, Indonesia and Metyl Orange (MO), $\mathrm{NaOH}, \mathrm{AlCl}_{3} \cdot 6 \mathrm{H}_{2} \mathrm{O}$, isopropanol and $\mathrm{TiOCl}_{2}$ all of these items were supplied from E.Merck

\section{Preparation of Photocatalyst (PILC Ti)}

Preparation of $\mathrm{TiO}_{2}$ coated on clay pillared alumina started from preparation of Kegin $\mathrm{Al}_{13}$ 
solution. This solution was prepared by mixing between $\mathrm{AlCl}_{3} .6 \mathrm{H}_{2} \mathrm{O} 0.4 \mathrm{M}$ and $\mathrm{NaOH} 0.88 \mathrm{M}$ solution under vigorously stirring until the ratio of $\mathrm{OH}-/ \mathrm{Al}=2.2$ reached and reflacted for $4 \mathrm{~h}$. the pillarization process was then conducted by dropping this solution into a clay dispersion at a ratio of $5.0 \mathrm{mmol} \mathrm{Al} / \mathrm{g}$ of clay without any aging process and calcination at $500{ }^{\circ} \mathrm{C}$ for 4 $\mathrm{h}$. The clay pillared alumina was noted as PILC. PILC Ti composites were prepared by an impregnation procedure using $\mathrm{TiOCl}_{2}$. Firstly, $\mathrm{TiOCl}_{2}$ was diluted with isopropanol to obtain a clear solution of varying $\mathrm{Ti}$ concentrations. This solution was slowly added to PILC dispersion with constant stirring of $6 \mathrm{~h}$ at room temperature. The solvent was evaporated at $30{ }^{\circ} \mathrm{C}$ under vacuum. The solid material was dried at $120{ }^{\circ} \mathrm{C}$ for $6 \mathrm{~h}$, then calcined at $450{ }^{\circ} \mathrm{C}$ for $4 \mathrm{~h}$ (PILC Ti). $\mathrm{TiO}_{2}$ with various Ti loading of $0.4,1.0$ and 3.0 mass \% were prepared. The photocatalysts were referred as PILC Ti-N where $\mathrm{N}$ indicates the $\mathrm{Ti}$ content.

\section{Photocatalyst Characterization}

A gas sorption analyzer (NOVA 1200e) was used to determine the nitrogen adsorption isotherms at $-196 \mathrm{C}$. The surface area was calculated by the BET equation. A Shimadzu $X$ 6000 powder diffractometer with $\mathrm{Cu}-\mathrm{K}$ radiation was used to obtain X-ray powder diffraction (XRD) patterns. The morphology and chemical contents of materials was observed by scanning electron microscopy (SEM JEOL 820). UV-vis diffuse reflectance spectra were obtained at $25{ }^{\circ} \mathrm{C}$ on a JASCO UNIDEC model V670 spectrometer equipped with an integrating sphere, where a BaSO4 plate was used as a reference.

\section{Photocatalytic Activity Test}

The photocatalytic activity evaluation of PILC $\mathrm{Ti}$ materials was carried out in a batch photoreactor. The reactor was made of a Pyrex glass beaker surrounded by a water jacket and four UV tube lamps (UVB lamp, 10 $\mathrm{W})$. Methyl Orange solution (MO) during the reaction was determined by photometry at 463 $\mathrm{nm}$ using a UV-visible spectrophotometer (HITACHI-U 2080).

\section{RESULTS AND DISCUSSION}

\section{Material characterization}

Figure 2 showed the fitures of the clay, pillared clay and pillared clay with various $\mathrm{TiO}_{2}$ concentration loaded on it using XRD.
Generally, The XRD patterns indicated spesific characterization of clay at $2 \theta=6.3^{\circ}\left(\mathrm{d}_{001}=14.9\right.$ $\AA)$ and $2 \theta=19.9^{\circ}(d=4.5 \AA)$ and pointed out that the pillarization has been done successfully in which it was indicated by decreasing of $2 \theta$ number (shifting to the left) from $6.02^{\circ}$ to $5.12^{\circ}$ which these two numbers belong to pillared clay and clay respectively. This phenomenon experienced due to the increasing of pillar height ( $d$-spacing $\left.\mathrm{d}_{001}\right)$ from replacing hydrated cation between two layers of clay with alumina, for detail it can be seen in table 1. The figure also exhibited that $\mathrm{TiO}_{2}$ dispersed on PILC in the form of anatase and rutile. Reflections of titania on PILC Ti were not observed when the $\mathrm{Ti}$ content was 0.4 mass $\%$. The position and intensity of the (001) reflection were not affected. The titania phase was identified when its content was 1.0 and 3.0 mass \%. At $225.1^{\circ}, 37.7^{\circ}$, and $53.8^{\circ}$ the (101), (004) and (105) reflections of tetragonal titania (anatase) were observed. With increasing titania content the (101) reflection of rutile at $27^{\circ}$ was found.

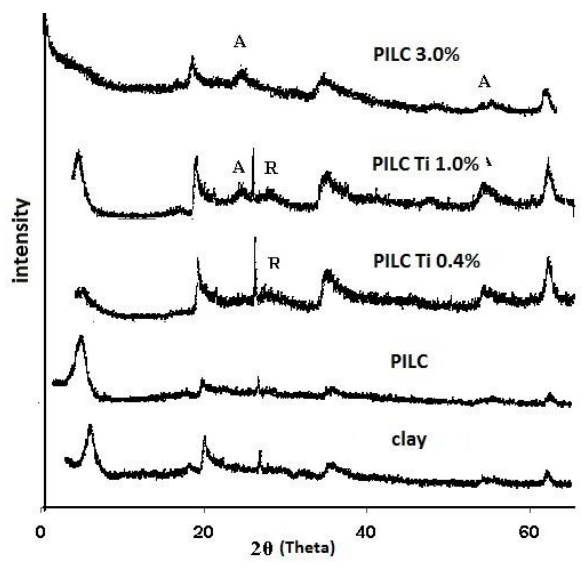

Figure 2: XRD Pattern of clay, PILC and PILC $\mathrm{Ti}$

Table 1: basal spacing and pillar height of clay, PILC and PILC Ti

\begin{tabular}{lccc}
\hline \multicolumn{1}{c}{ Sample } & $2 \theta$ & $\mathrm{d}_{001}$ & $\begin{array}{c}\Delta \mathrm{d}_{001}=\mathrm{d}_{001^{-}} \\
9.6 \AA\end{array}$ \\
\hline Clay & $6.02^{\circ}$ & $14.68 \AA$ & $5.08 \AA$ \\
PILC & $5.12^{\circ}$ & $17.26 \AA$ & $7.66 \AA$ \\
PILC Ti $0.4 \%$ & $5.50^{\circ}$ & $16.06 \AA$ & $6.46 \AA$ \\
PILC Ti $1.0 \%$ & $5.66^{\circ}$ & $15.61 \AA$ & $6.01 \AA$ \\
PILC Ti $3.0 \%$ & $5.30^{\circ}$ & $16.67 \AA$ & $7.07 \AA$ \\
\hline
\end{tabular}

Smaller titania particle was identified in pillared clay (PILC) using UV-visible diffuse reflectance spectra (Fig.3). Based on the figure, there was blue shift in three $\mathrm{TiO} 2$ in PILC where PILC 
0.4\% PILC $\mathrm{Ti}$ 1.0\% PILC $\mathrm{Ti} 3.0 \%$ and $\mathrm{TiO} 2$ have edge wavelength $\left(\lambda_{\mathrm{g}}\right) 389.2 \mathrm{~nm}, 338.7$ $\mathrm{nm}$ and $389.2 \mathrm{~nm} .398 \mathrm{~nm}$ respectively. $\mathrm{TiO}_{2}$ in the three PILCs having smaller edge wavelength than that $\mathrm{TiO}_{2}$ in bulk led the increasing of band gap energy $(\mathrm{Eg})$. The $\mathrm{Eg}$ was calculated using equation, $\mathrm{E}_{\mathrm{g}}=h c / \lambda$ in which $h=6.626 \times 10^{-34} \mathrm{Js}, c=3 \times 10^{8} \mathrm{~m} / \mathrm{s}$ and $\lambda=$ wave length. The yields of calculation can be seen at table 2 .

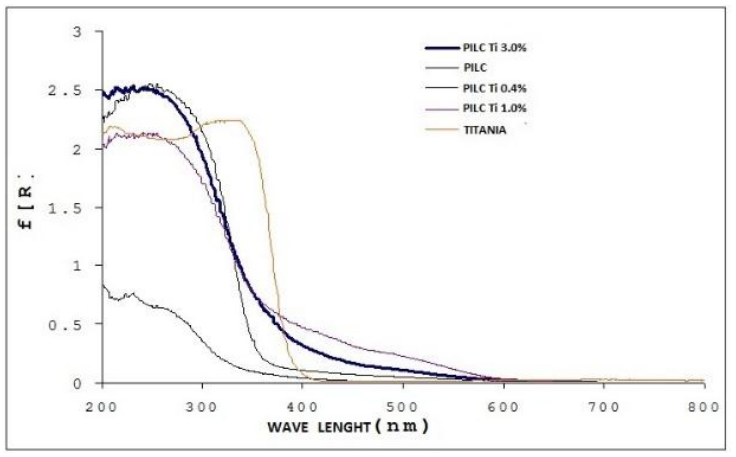

Figure 3: UV-visible diffuse reflectance of PILC $\mathrm{Ti}$

Table 2: band gap energy of $\mathrm{TiO}_{2}$ on PILC

\begin{tabular}{lcccc}
\hline $\begin{array}{l}\text { Photoca } \\
\text { talyst }\end{array}$ & $\mathrm{TiO}_{2}$ & $\begin{array}{c}\mathrm{PILC} \\
\mathrm{Ti} \\
0.4 \%\end{array}$ & $\begin{array}{c}\mathrm{PILC} \mathrm{Ti} \\
1.0 \%\end{array}$ & $\begin{array}{c}\mathrm{PILC} \\
\mathrm{Ti} \\
3.0 \%\end{array}$ \\
\hline$\lambda_{\mathrm{g}}(\mathrm{nm})$ & 398 & 338.7 & 389.2 & 389.2 \\
$\mathrm{E}_{\mathrm{g}}(\mathrm{eV})$ & 3.11 & 3.66 & 3.19 & 3.19 \\
\hline
\end{tabular}

From table 2, it was known that PILC Ti $0.4 \%$ has the highest band energy campared to the rests. It occurred because $\mathrm{TiO}_{2} 0.4 \%$ was well dispersed or homogeneous distributed on PILC whereas $\mathrm{TiO}_{2} \quad 1.0 \%$ and $3.0 \%$ distrubution in PILC was not well flatten and tend to experince agregrates on surface of PILC in which it is clearly seen in figure 4.

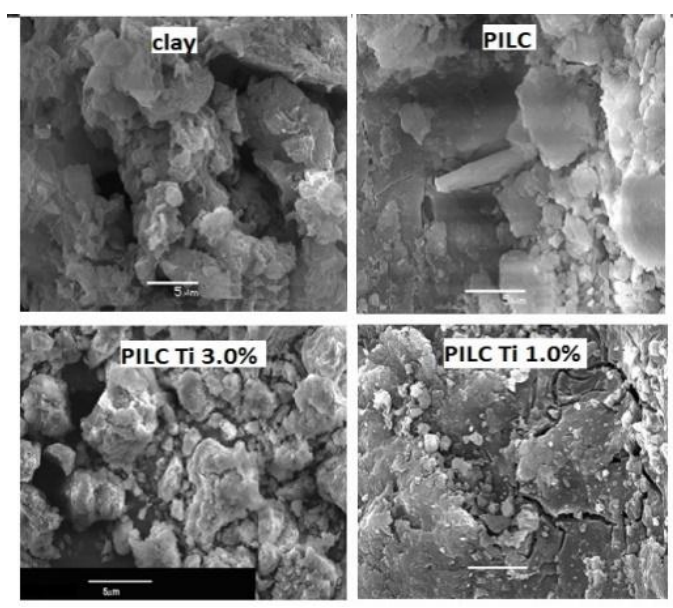

Figure 4: SEM image of clay, PILC and PILC $\mathrm{Ti}$

From the fig. 4, it was obviously seen that there was a difference between clay, PILC and PILC Ti surface morphology. The structure of PILC and PILC showed heterogeneous and complex morpohogy due to the forming of $\mathrm{Al}$ and $\mathrm{Ti}$ oxide. It was proven from the figure that the higer Ti loaded, the more agregate existed.

Pillarization and $\mathrm{TiO}_{2}$ loaded on PILC caused alteration on surface area including pore distribution (figure 5), spesific surface area and pore volume (table 3 ).

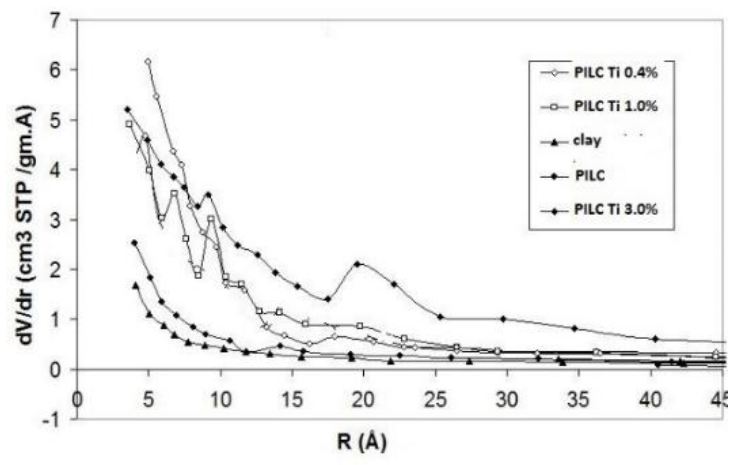

Figure 5: Pore size distribution of clay, PILC and PILC Ti

Table 3: Spesific surface area and total pore volume of materials

\begin{tabular}{ccc}
\hline Materials & $\begin{array}{c}\text { Specific surface } \\
\text { area }\left(\mathrm{m}^{2} / \mathrm{g}\right)\end{array}$ & $\begin{array}{c}\text { pore volume } \\
(\mathrm{cc} / \mathrm{g})\end{array}$ \\
\hline Clay & 68.20 & 15.36 \\
PILC & 197.87 & 58.37 \\
PILC Ti 0.4\% & 100.67 & 31.58 \\
PILC Ti 1.0\% & 144.87 & 43.10 \\
PILC Ti 3.0\% & 128.32 & 35.34 \\
\hline
\end{tabular}

There was a reducing of specific surface area after pillariazation from $68.20 \mathrm{~m}^{2} / \mathrm{g}$ to 197.87 $\mathrm{m}^{2} / \mathrm{g}$. This took place due to existance of alumina as the pillar spliting layers of clay so that surface area automatically rise. It is also clearly exibited in figure 5 and figure 2 in that PILC had more meso pore distribution than that of clay. The increasing of pore size by splitting led to open the way for $\mathrm{TiO}_{2}$ to enter the pores and lessen amount of pore. Like it was that after dispersion of $\mathrm{TiO}_{2}$ (PILC Ti $0.4 \%$ ) the specific surface area decreased and achieved 100.67 $\mathrm{m}^{2} / \mathrm{g}$. Interestingly, PILC Ti $1.0 \%$ and PILC Ti 
$3.0 \%$ had more specific surface area than that of PILC $\mathrm{Ti} 0.4 \%$. The lack of pore in that two materials because the $\mathrm{TiO} 2$ tend to penetrate on the surface of clay rather than to come in it.

\section{Photodegradation of Methyl Orange (MO)}

In this test, MO photodegradation was conducted by using three materials, PILC Ti $0.4 \%$, PILC Ti $1.0 \%$ and PILC Ti $3.0 \%$, in order to find the most effective photocatalyst. It was aimed to anticipate the effectiveness of using the photocatalyst during reaction. Figure 6 showed the MO photodegradation with various TiO2 concentrations loaded.

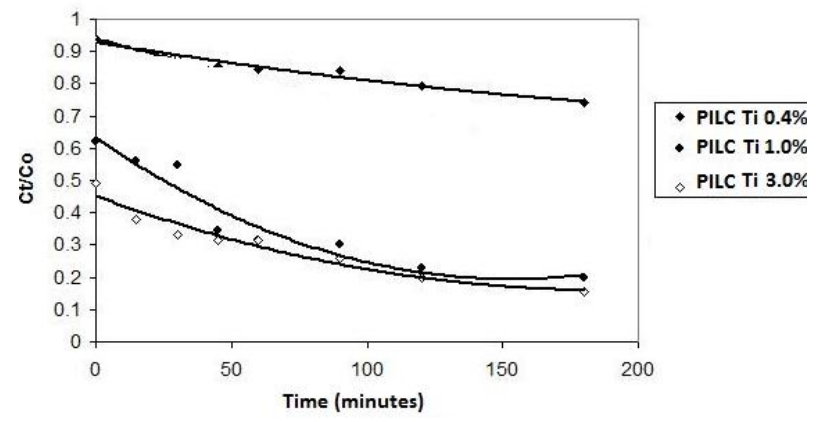

Figure 6: MO photodegradation

Table 4: constant rate of PILC Ti

\begin{tabular}{cc}
\hline Photocatalyst & $k$ (minutes $\left.^{-1}\right)$ \\
\hline PILC Ti $0.4 \%$ & $2.18 \times 10^{-3}$ \\
PILC Ti $1.0 \%$ & $6.67 \times 10^{-3}$ \\
PILC Ti 3.0\% & $5.86 \times 10^{-3}$ \\
\hline
\end{tabular}

In that picture, MO concentration used in beginning of reaction is $1.5 \mathrm{M}$ but in zero time (0 minutes) there was began at different concentration before the illumination was conducted. The distinction occurred because the discrepancy of weigh loaded in the system has specific ability to adsorb the MO [12-13]. To determine which one is the most effective among three photocatalysts the equation bellow had been employed in order to find the highest yield of $k$ (constant rate).

$$
-\frac{d C}{d t}=k \cdot C
$$

Which $k$ constant rate, $t$ time and $c \mathrm{MO}$ concentration. Based on the calculation yield, PILC Ti $1.0 \%$ had the highest value of which was $6.67 \times 10^{-3}$ (table 4 ). The excess mount of catalyst in the system enabled the photodegradation collapse in its activity like what the PILC $\mathrm{Ti} 3.0 \%$ experienced. This is caused by deactivating of actives site with other active sites in ground state when photodegradation took place [14-17]

\section{CONCLUSION}

Based on the results, this paper concluded that coating $\mathrm{TiO} 2$ on clay pillared by alumina for MO photodegradation has been conducted successfully. The pillarization led the basal spacing and specific surface area of clay increase and did not cause destructive in the clay structure as well. TiO2 coated on pillared clay shaped in anatase and rutile form in which PILC $\mathrm{Ti} 1.0 \%$ was the most effective photocatalyst for MO photodegradation.

\section{References}

[1] Ayodele, O. B., Lim, J. K., \& Hameed, B. H. (2012). Pillared montmorillonite supported ferric oxalate as heterogeneous photo-Fenton catalyst for degradation of amoxicillin. Applied catalysis a: general, 413, 301-309.

[2] Fatimah, I., Sumarlan, I., \& Alawiyah, T. (2015). Fe (III)/TiO2-montmorillonite photocatalyst in photo-Fenton-like degradation of methylene blue. International Journal of Chemical Engineering, 2015.

[3] Chen, D., Zhu, H., \& Wang, X. (2014). A facile method to synthesize the photocatalytic TiO2/montmorillonite nanocomposites with enhanced photoactivity. Applied surface science, 319, 158-166.

[4] Linsebigler, A. L., Lu, G., \& Yates Jr, J. T. (1995). Photocatalysis on TiO2 surfaces: principles, mechanisms, and selected results. Chemical reviews, 95(3), 735-758.

[5] Cong, Y., Zhang, J., Chen, F., Anpo, M., \& He, D. (2007). Preparation, photocatalytic activity, and mechanism of nano-TiO2 co-doped with nitrogen and iron (III). The Journal of Physical Chemistry C, 111(28), 10618-10623.

[6] Shi, J. W. (2009). Preparation of Fe (III) and Ho (III) co-doped TiO2 films loaded on activated carbon fibers and their 
photocatalytic activities. Chemical Engineering Journal, 151(1-3), 241-246.

[7] Hakim, Y. Z., Yulizar, Y., Nurcahyo, A., \& Surya, M. (2018). Green Synthesis of Carbon Nanotubes from Coconut Shell Waste for the Adsorption of $\mathrm{Pb}$ (II) lons. Acta Chimica Asiana, 1(1), 6-10.

[8] Gil, A., Korili, S. A., Trujillano, R., \& Vicente, M. A. (Eds.). (2010). Pillared clays and related catalysts. Springer Science \& Business Media.

[9] Jalil, M. E. R., Vieira, R. S., Azevedo, D., Baschini, M., \& Sapag, K. (2013). Improvement in the adsorption of thiabendazole by using aluminum pillared clays. Applied Clay Science, 71, 55-63.

[10] Kloprogge, J. T. (1998). Synthesis of smectites and porous pillared clay catalysts: A review. Journal of Porous Materials, 5(1), 5-41.

[11] Mori, K., Kawashima, M., Che, M., \& Yamashita, H. (2010). Enhancement of the Photoinduced Oxidation Activity of a Ruthenium (II) Complex Anchored on Silica-Coated Silver Nanoparticles by Localized Surface Plasmon Resonance. Angewandte Chemie International Edition, 49(46), 8598-8601.

[12] Al-Qaradawi, S., \& Salman, S. R. (2002). Photocatalytic degradation of methyl orange as a model compound. Journal of
Photochemistry and photobiology A: Chemistry, 148(1-3), 161-168.

[13] Konstantinou, I. K., \& Albanis, T. A. (2004). TiO2-assisted photocatalytic degradation of azo dyes in aqueous solution: kinetic and mechanistic investigations: a review. Applied Catalysis B: Environmental, 49(1), 1-14.

[14] Zhang, Y., Gan, H., \& Zhang, G. (2011). A novel mixed-phase TiO2/kaolinite composites and their photocatalytic activity for degradation of organic contaminants. Chemical Engineering Journal, 172(2-3), 936-943.

[15] Chen, Q., Wu, P., Dang, Z., Zhu, N., Li, P., Wu, J., \& Wang, X. (2010). Iron pillared vermiculite as a heterogeneous photo-Fenton catalyst for photocatalytic degradation of azo dye reactive brilliant orange X-GN. Separation and Purification Technology, 71(3), 315-323.

[16] Chen, L. C., Tsai, F. R., \& Huang, C. M. (2005). Photocatalytic decolorization of methyl orange in aqueous medium of $\mathrm{TiO} 2$ and $\mathrm{Ag}-\mathrm{TiO} 2$ immobilized on $\mathrm{Y}$ Al2O3. Journal of Photochemistry and Photobiology A: Chemistry, 170(1), 7-14.

[17] Jo, W. K., \& Tayade, R. J. (2014). Recent developments in photocatalytic dye degradation upon irradiation with energyefficient light emitting diodes. Chinese Journal of Catalysis, 35(11), 1781-1792. 